This work has been submitted to NECTAR, the Northampton Electronic Collection of Theses and Research.

\title{
Book Section
}

Title: The 'Burden' of the feminine: Frank Sargeson's encounter with Katherine Mansfield

Creator: Wilson, J. M.

Example citation: Wilson, J. M. (2015) The 'Burden' of the feminine: Frank Sargeson's encounter with Katherine Mansfield. In: Ailwood, S. and Harvey, M. (eds.) Katherine Mansfield and Literary Influence. Edinburgh: Edinburgh University Press. pp. 207-218.

It is advisable to refer to the publisher's version if you intend to cite from this work.

Version: Accepted version

Official URL: http://www.euppublishing.com/book/9780748694419

http://nectar.northampton.ac.uk/7607/

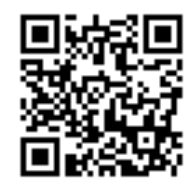




\section{The 'Burden' of the Feminine: Frank Sargeson's Encounter with Katherine Mansfield}

\section{Janet Wilson}

Katherine Mansfield had an ambivalent posthumous reputation in the country of her birth in the decades following her death. Despite her international fame as a literary modernist within a decade she was being treated with suspicion by the cultural nationalists of the 1930s and 1940s: the poets, Allen Curnow, Dennis Glover and A. R. D. Fairburn, and Frank Sargeson, who pioneered the Kiwi vernacular in prose and saw Mansfield as a rival to his own precedence in the national short story tradition. These writers considered her modernist, impressionist style as inimical to their ambitions for a cultural nationalism, which were grounded in a preoccupation with the local and which valued realism for its capacity to authenticate the project of mapping the cultural landscape. C. K. Stead attributes this to the 'burden' of influence Mansfield represented at a time when the new Dominion was aiming to develop its literary prose traditions independent of England and Europe. To them, she represented a 'problem requiring a strategy'. ${ }^{1}$ Sargeson, in particular, needed to clear a space for his own voice to assume its place in the nationalist prose tradition. From the 1930s to the 1950s, his prose style was indelibly linked with social realism, leading to the critical orthodoxy that it represented an unrivalled representation of New Zealandness. ${ }^{2}$

This essay is situated in relation to the critical commonplace that the contrasting literary modes and prose styles of Frank Sargeson and Katherine Mansfield - of hard-edged realist writing and the miniaturist 'subjectivist' writing of impressionism - laid the foundation for the two traditions in New Zealand prose. By contrast to the typology outlined by Lawrence Jones in 1987 and following on from critics like W. H. New, Mark Williams and Joel Gwynne, ${ }^{3}$ it identifies similarities in Mansfield and Sargeson's artistic orientation, traceable to their critique of colonial culture and society: namely, an aesthetics of fragmentation, resistance to normative gender constructions of colonial society and their use of symbolic modes of representation. These aesthetic values suggest some alignment of their styles, but Mansfield can also be traced as an intertextual presence in Sargeson's work, alongside an implied gendered critique of her female voice and attitudes. This essay further argues that Sargeson developed his stylistic repertoire by adapting Mansfield's techniques of impressionism and impersonation to his ambivalently gendered viewpoint in order to nuance masculine vulnerability and unrequited love. This specific influence of Mansfield upon Sargeson, which has not been remarked upon until now, will be illustrated with reference to his story, 'A Man and his Wife' (1939), ${ }^{4}$ in which he surreptitiously draws on Mansfield's last story, 'The Canary' (1923), 'writing back' in a rural colonial context and voice to her metropolitan female discourse.

The Mansfield 'problem' for Sargeson was the influence of her gendered style of writing on younger women writers: ${ }^{5}$ namely Robin Hyde and Gloria Rawlinson, as well as Mansfield imitators in Australia such as the novelist Eleanor Dark and the New Zealandborn novelist, Jean Devanny. ${ }^{6}$ He implied that such imitation would misrepresent both New Zealand and its literary traditions: 'Mansfield ... imposed a pattern on our writing and ... hosts of young women wrote Mansfield stories'. 7 In a radio talk on Mansfield broadcast on 28 July 1948 he spoke of her as writing in the 'feminine tradition', specifically 'the minor tradition' [italics in original], whose aesthetic reflects the 'tendency to be concerned with the part rather than the whole ... to make your story depend for its effectiveness on isolated details and moments of life' ${ }^{8}$ What he and his circle denigrated as the fussy, miniaturising stylistic traits of Mansfield and her followers is not mentioned. ${ }^{9}$ In order to ensure the 
continuing fashion for raw realism, the prose style of the literary movement that included writers like John Mulgan, and Dan Davin and, by implication, to protect his own sexual proclivities under the cover of heternormative masculinity, Sargeson distanced himself from Mansfield's impressionism.

By 1970, however, Sargeson was identifying himself with Mansfield by claiming his influence to be equivalent to hers. In stating that 'there were two tragedies in New Zealand literature - one was Katherine Mansfield and the other was Frank Sargeson' ${ }^{10}$ - he appeared to subscribe to the two traditions theory including its subsequent simplifications. Yet his view of himself as more of a symbolic realist than 'a realist or even a naturalist writer' ${ }^{11}$ also seems to gesture towards Mansfield and the 'feminine' tradition. W. H. New develops this, claiming that 'there is more Mansfield in Sargeson that at first seems apparent', ${ }^{12}$ and Joel Gwynne and Mark Williams also argue that Sargeson's demotic, colloquial style and discursive construction of a social order belie his use of techniques associated with impressionism such as symbol, image and epiphany in order to capture individual moments of intensity, intimacy and transcendence. ${ }^{13}$ Gwynne identifies in Sargeson's first person story, I For One... (1952), similarities of aesthetic practice; ${ }^{14}$ that Sargeson's ventriloquising of a female voice borrows from Mansfield appears in the sly allusion to the speaker, named as Katherine, who sees as 'a stranger, [...] one set apart'. ${ }^{15}$ Simon During also implies Sargeson was extending his realism into modernism, to distance himself from provincial society and its heterosexual norms, just as modernism did in opposition to bourgeois culture and associated forms of literary realism. ${ }^{16}$ Finally, recent scholarship on Sargeson as a gay writer who introduces veiled homoerotic subtexts and a 'butch laconic realism' argues that his inarticulate drifting characters mask yearning and unfulfilled desire, and are vulnerable to social bias and discrimination. John Newton, for example, exposes the liminality of Sargeson's place as a closet gay writer who ensured his continued acceptance in New Zealand's homophobic society as its representative voice. ${ }^{17}$ These literary and cultural critiques have prepared the ground for an intertextual reading of Sargeson in relation to Mansfield by identifying his balancing of contradictory roles, identities and expectations, to give covert representation to the marginalised gay man under the guise of a virile, rugged style, as evidenced in the homoerotic subtexts of stories like 'Good Samaritan', 'White Man's Burden' and 'The Hole that Jack Dug', that depend on pun, word play and innuendo. By 1940, when his second collection A Man and His Wife was published, Sargeson looked to Mansfield to develop moral and stylistic complexity, while simultaneously critiquing her through a realist lens; he adapted as a strategy of concealment her symbolist method in 'The Canary' to the narrative technique of indirection and the subtext of unfulfilled desire of the collection's disingenuously-titled, eponymous story, 'A Man and his Wife'.

The overlapping features of Mansfield and Sargeson's practice can be traced to their colonial origins and critical responses to the limitations of provincial culture. Both dealt with white settler dislocation by positioning themselves at odds with its existing cultural frames and developing a voice of resistance to its philistinism, materialism and puritanism. Their decision to write in genres such as the sketch and story, often with first person narrators, suggests a wish to speak of the experience of colonial life in semi-autobiographical form. Yet both felt a need to move beyond the limitations of short fiction and wrote longer stories like Mansfield's 'Prelude' (1918) or Sargeson's novella, 'That Summer' (1938-40). Furthermore, despite their very different literary modes of symbolic realism and modernist impressionism they shared an aesthetic preoccupation with symbolism and epiphany, which draws on the sounds and cadences of the spoken voice, and displays the fragmented or fractured narrative 
structures, forms of which are found in all the avant-garde movements of the earlytwentieth century. 'The Canary' exemplifies Mansfield's symbolist and impressionist techniques: a plotless situation, the dispensing of the external narrative voice in order to focus on the speaker's thoughts and feelings; extended impersonation of her speaking voice through dramatic monologue and verisimilitude. Sargeson also developed the stylisation of his first person narrator's voice for his brand of realism. His representations of virile yet inarticulate masculinity, so favoured by his contemporaries, drew on entrenched stereotypes of the colony as the stronghold of the athletic man, shaped by the Great Depression, physical labour and war, an ideology of physical strength and pragmatism that was central to a national narrative of selfsufficiency.

Other shared aesthetic preferences appear in the way both adopted and transformed inherited modes and genres - the yarn, sketch and anecdote, associated with the oral traditions of early colonial cultures - in order to give voice to outlaw figures and social outsiders, waifs, misfits and itinerants. ${ }^{18}$ Mansfield was probably familiar with the frontier stories of Henry Lawson, ${ }^{19}$ while Sargeson introduces intertexts from Lawson, Sherwood Anderson and Mark Twain, literary precursors who mediate and inform his conversational stylisation of the colonial encounter. Mansfield's deracinated characters in her three 'outback' stories, 'The Woman at the Store', 'Ole Underwood' and 'Millie', are adaptations of her earlier observations of New Zealand outback life to the modernist demand for the primitive and savage. ${ }^{20}$ Both writers feature underdeveloped, psychologically disconnected characters who lack insight into their motives and whose behaviour reflects the cruelty of life and thinness of civilisation. The stories recapitulate similar pioneering characteristics: arbitrary death, irrational behaviour, the loss of moral order. A murder lies at the heart of Mansfield's; her structures of psychological disorder are mirrored in the violent deaths and explosive climaxes of Sargeson's stories like 'A Great Day', 'I've Lost My Pal', 'A Good Boy' and 'Sale Day'.

They also share a critique of normative gender structures. Mansfield's stories like 'The Daughters of the Late Colonel', which interrogate and reframe images of women as oppressed and exploited, are comparable to Sargeson's attempts to create more representational space for the covert, frustrated homosexual in a homophobic society. Mansfield's resistance to patriarchy finds an echo in Sargeson's concealed alienation from bourgeois values and heterosexual norms. The restlessness and mobility of their protagonists constitute a shared reproach to and apparent rejection of family life. Sargeson embraces drifters, wanderers, the rootless. In 'That Summer', the hero has 'itchy feet', a casual lifestyle, money slips through his fingers and he moves about in a search of love. Mansfield's female protagonists in stories like 'An Indiscreet Journey' and 'The Little Governess' feature solitary s seeking experience as travellers who enter new spaces and dream or improvise alternative versions of their identities. Also reflecting the emphasis on marginal and socially disparate individuals are their characters' transient living arrangements and alternative types of accommodation. Boarding houses, hotels and pensions, often with alienating impersonal officials, feature in Mansfield's stories, while Sargeson's drifting, unemployed men dwell in makeshift spaces: converted barns and stables, old washhouses in people's backyards. Narrative fracture, discontinuity, disjunction and interruption which illustrate the tentativeness of national discourses then, therefore, are vehicles of social critique, but also mirror contemporary social realities: Mansfield's restlessness reflects the mobility of single women in the early twentieth century; Sargeson's 
stories like 'I've Lost my Pal' and 'A Man and his Wife' draw on the domestic upheaval of working class men during the 1930s slump.

Both writers in different ways sought new narrative positions to articulate the individual's experience in a manner that might inflect and interpret nation formation. Mansfield was motivated to write stories about her New Zealand childhood by nostalgia and a longing for reconnection from a distance. Sargeson, aiming to establish a discourse of alienation and critique from within to create the illusion of collective belonging, adapted European and American literary models to local conditions, and engaged with the orthodoxies of canonical writing as in'The Making of a New Zealander. ${ }^{21}$ Being positioned tangentially or outside national social norms made both conscious of the gaps in cultural consciousness represented by fundamental instabilities in categories of fiction. Their narratives offer in a form of ambivalent identification, a sense of what it might be to become a nation. In Homi Bhabha's terms, they function as representations that 'move between different cultural formations and social processes without a "centred" causal logic'. ${ }^{22}$ An awareness of dominant social exclusions, limited linguistic structures and categories contribute to their shared sense of approximation and tentativeness in positioning their gendered difference from national hegemonies. These parallel images of doubt, reticence and disconnection illustrate Bhabha's point, drawing on Erich Gellner, that questions of the nation as narration can only be posed in that impasse between 'the shreds and patches of cultural signification', the arbitrary historical inventions and 'the certainties of national pedagogies'. ${ }^{23}$

Similarities between Mansfield and Sargeson -- of the questioning or denial of self in fiction, and the hesitation over familiar categories of national self definition -- therefore suggest an embryonic formative positioning, enabling the possibility of writing that embraces the idea of the nation. Sargeson's writing with its multi-layered allusions and associations, represents the uncertainty and inconclusiveness of literary inventions of the nation by implying that more than one cultural model of New Zealandness could be incorporated into the realist mode. By the late 1930s there was sufficient cultural distance from Mansfield for him to redeploy her tropes and values to interrupt and complicate its monocultural emphasis. Although Mansfield's 'outback' stories are read in relation to New Zealand regional fiction, ${ }^{24}$ it was her 'feminine' metropolitan themes that Sargeson turned to, implicitly counterpointing their different registers, styles and modes to his rural, realist settings. The contrast between the middle-class narrator's effusion of grief in 'The Canary', uttered in an affective register, and the laconic voice of the displaced male narrator of 'A Man and his Wife' is so striking as to confound any suggestion of direct influence.

The canary in Sargeson's story, as a symbol of 'Perfect company', 25 worshipped by Ted, the narrator's working-class mate, recalls Mansfield's lamenting narrator's worship of her pet. The bird's narratological function, however, is to bridge competing social-sexual motivations - the narrator's latent homosexual desire for Ted, Ted's decision to return to his wife after the bird flies off and the wife's willingness to resume heteronormative sexual relations after her husband had seemingly adapted to the comradeship of single-man Depression life. Sargeson develops Mansfield's interweaving of voice, death and loss in 'The Canary' in order to deepen his thematic preoccupation with acts of communication and to foreground the oblique exchanges between the narrator and his mate Ted, and between Ted and his wife, dog, and canary. ${ }^{26}$ His pioneer models of outback writing, Sherwood Anderson, Mark Twain, and Henry Lawson, would not have provided the symbolic frame or techniques of 
impersonation required to elevate his art above that of parable or sketch. But if 'The Canary' is read as a concealed intertext of 'A Man and his Wife', then Sargeson's transposition of Mansfield's female narrator's pleasure in her canary to Ted's enjoyment in his, and of her lament at the bird's death to Ted's decision at his bird's flight and then the narrator's unvoiced disappointment at Ted's departure, reinvigorates his social realism and helps assert the ontological priority of his own universe. W. H. New notes that 'it is this control over speech - developing a voice with which to represent the voiceless sensibility - that Sargeson works out his own artistic medium'; ${ }^{27}$ yet it has not been observed how much this voice excludes and supplants other voices and styles, such as Mansfield's, even mocking them indirectly in order to gain its prominence.

'A Man and his Wife' is a Depression story set in the North Island. Sargeson's working-class narrator, living with other relief workers in sheds and washhouses, speaks a colloquial Kiwi idiom. Male bonding comes from social egalitarianism and the destabilising of gender distinctions: the narrator says 'in bad times ... people's habits aren't quite the same', that odd kinds of living arrangements caused by the slump create a 'certain sort of comradeship' ${ }^{28}$ The story turns on the fact that the narrator's mate, Ted, seems to prefer the company of 'our gang' to that of his wife, while the canary represents a new level of communication. But in the end, despite considerable badinage and mocking of women, Ted returns to his marriage, implying that women are essential for social normality and stability. Mansfield's story, by contrast, despite its Wellington background, is set in a European pension. Her middle class narrator, with an uninflected accent but sentimental tone, is at odds with her three male boarders who call her 'the Scarecrow' ${ }^{29}$, isolated in her grief at the bird's death.

Despite these differences in style, mode and setting, significant contiguities of theme and character hint at Mansfield's influence. Both stories are told in the first person by vulnerable, lonely narrators whose devotion to a canary separates them from other company. 'A Man and his Wife' overlaps with its precursor by focusing on the canary's heightened meaning for its owner due to its entertaining antics, communicative capacities and humanlike voice. The tragedy of the bird's death inspires Mansfield's narrator's lament at being left alone, while the bird's flight in 'A Man and his Wife' catalyses the anti-climactic denouement, following Ted's decision to abandon the narrator (as the latter sees it) and return to his wife. ${ }^{30}$ The narrator's sorrowful realisation of the lost opportunity to articulate his latent attraction to Ted, his repressed desires, leads to his role in the renewed marriage in which as a third presence he opens up a new space for heterosexual and homoerotic relations to coexist: ${ }^{31}$ 'it wasn't long before I was going round regularly twice a week for a game of cards with the pair of them'. ${ }^{32}$

The loss of the canary as the medium of ideal communication and symbol of perfect union marks an irreversible change in the scheme of things. Mansfield's canary symbolically represents her intertwined art and life; her identification with the bird's imprisonment, for example, appears in the analogy in a letter to her cousin, Elizabeth von Armin, to her 'little stories like birds bred in cages'. ${ }^{33}$ The bird's lifeless body signifies the narrator's mortality ('something seemed to die in me'), yet her invocation of its presence - the hook on which his cage hung, and the words, 'I feel he is not quite forgotten' - constitute some redemption from silence and apparent oblivion, hinting at art's capacity to immortalise. The comment, 'I should like to think it was there always after my time', also implies perpetuation beyond the textual present. ${ }^{34}$ In Sargeson's story, the canary, at first a neutral figure of companionship, 
comes to symbolise for the narrator the undeveloped, untested male relationship and the possibility of love, which ends when the bird flies away. Ted's laconic explanation for returning to his wife, because she 'never let me down', articulates the core value of Sargesonian mateship. ${ }^{35}$ Ted verbally attributes to her the comradeship he shared with the narrator, even appropriating the idiom that the latter would have used of himself, so 'betraying' the narrator's desire. The concluding exchange in Sargeson's tautest, most enigmatic style constitutes a failed epiphany. The narrator's disappointment at the dashing of his aspirations in this cross-wired reversal of expectation remains unexpressed: "'I've still got the wife, he said. Yes, I said. The wife never let me down he said. No. I said. It was all I could think of to say". ${ }^{36}$ In this oblique conclusion which the reader must decipher, Sargeson demonstrates how he is Mansfield's disciple, that he has learnt from her 'art of inferential narrative' the value of absence or silence to fix 'attention on the inarticulate (or at least inarticulated) sources of people's motivation'. ${ }^{37}$

Both stories demonstrate a preoccupation with reciprocity in communication by recording the limits of the bird's transient presence and ability to articulate, entertain, bestow and receive love. The canary symbolises the power of the voice, of song-making as an emblem of tonal, sonic harmony. In this context, and as performer and mimic of the human voice, it offers a kind of intimacy between different versions of the self that exceeds that offered by human relationships. Ted refuses food and the company of the narrator's gang because 'he'd sooner just sit there and kid to the bird'; ${ }^{38}$ Mansfield's narrator details her bird's 'little entertainment,' acclaiming his performance with "You're a regular little actor". ${ }^{39}$ This is all the more poignant because of the bird's associations with enslavement and constraint through being caged and its instinct for liberation and freedom. Sargeson's narrator, for example, observes that after Ted's bird flies away 'in the tree it sounded as though it was singing better than ever before'. ${ }^{40}$

The greatest contrast between the stories is in their mode of address. The dramatic monologue of Mansfield's final story, her impersonation of an emotional, middle-aged woman whose intense endearments - "There you are my darling" - suggest excessive attachment and affection, is widely appreciated as her farewell to her art. ${ }^{41}$ Conversation is emulated, as with attribution of 'Missus! Missus!' to the canary's notes. ${ }^{42}$ The fading out of her voice and its re-emergence from silence is implied typographically by the use of ellipses at the beginning of some paragraphs, and of dashes, especially in the conclusion, arguably symbolising the flickering of the consciousness in its last moments. These typographically marked elisions and omissions can be read as hinting at death in the midst of life, and the concluding rhetorical questions - 'But isn't it extraordinary that under his sweet joyful little singing, it was just this - sadness? - Ah, what is it? - that I heard ${ }^{43}$ - implies the beginning of an unbroken silence after voice disappears, just as the presence of the voice listening is a reminder that the sounds and cadences of speech carry farther than words into that silence.

Sargeson's narrator, by contrast, is an anecdotalist whose laconic, casual mode of talking about 'my cobber ... on relief work like myself' ${ }^{44}$ is the story's trademark. Narrative fracture and fragmentation point to the suppression of the narrator's uncertain affections and his hesitations and aspirations concerning Ted, in contrast to the expressive function of the breaks and interruptions in the textual surface of Mansfield's narrator's monologue, which are correlated to her linked themes of silence, death and loss. What is unsaid and what the conclusion points to in hinting at the narrator's perplexity about the renewed marriage, make this a narrative of repressed love, to which the sparse title, 'A Man and His Wife', is a provocative counterpoint. 
The degree to which Sargeson was borrowing from Mansfield and the subtlety of his appropriation of her text can be inferred from specific details. In both stories the owner's elevation of the canary above a highly-prized predecessor in their affections confirms its unsurpassing value. Ted had a dog which 'was nothing special ... but Ted was certainly fond of it'; ${ }^{45}$ he talked to the dog more than to his wife, causing their separation. In 'The Canary' the predecessor is the unlikely entity of the evening star but 'after he came into my life I forgot the evening star; I did not need it any more'. ${ }^{46}$ Sargeson's close reading of Mansfield's story and transposition of its middle-class concerns into a socialist-realist mode, overruling and displacing the 'feminine' voice in an act of curtailment, can be inferred from other details. The "nice fox terrier" 47 that the washerwoman in Mansfield's story recommends as an alternative pet is echoed in the role of Ted's dog. The single reference to a Chinaman when the cobbers 'had to raid a Chinaman's garden after we'd spent all our money in the pubs', ${ }^{48}$ recalls the Chinaman in Mansfield's story who comes to the door with the canary and other birds to sell. Finally, 'A Man and his Wife' can be read as a rural, realist recasting of Mansfield's middle-class narrator's values, a provincial 'writing back' to and implicit mocking of her metropolitan voice. Her hyperbolic lament at the bird's death, with its intimations of mortality - 'When I found him, lying on his back, with his eye dim and his claws wrung, when I realized that never again should I hear my darling sing, something seemed to die in me' - is juxtaposed with Sargeson's narrator's unemotional reflection on birds who die as parasites trapped in the fur or wool of other animals: 'once on a sheep farm I found a little skeleton tangled in the wool on a sheep's back' ${ }^{49}$ Mansfield's narrator's image of the death of a pampered, piteous pet is subverted by this rural recasting in which death is represented as arbitrary, cruel and utterly anonymous.

With these likely intertextual allusions to 'The Canary' Sargeson acknowledges Mansfield as rival and predecessor, and repositions her concerns in the context of more democratic, egalitarian working-class values, deliberately masculinising them. $\mathrm{He}$ 'nationalises' her interior monologue by a middle-aged bourgeois woman as a New Zealand yarn told by a working-class male. Moreover, he suggestively picks up and reframes her theme of perfect communication in order to give new voice to his anxieties about the possibility of effective and fulfilling male relationships. The canary's voice adds a new dimension to the story's thematic preoccupation with communication; for the idea of complete fulfillment in conversations with the canary, a pet with a near-human voice, which Mansfield initiates, is thematically enriching. It brilliantly elevates the implications of the outcome and the inability to communicate implied in the narrator's inarticulate comment " "It was all I could think of to say"'-- as the meaning of his repressed feelings about Ted dawns on him.

A Man and his Wife was reprinted three times in less than four years and by the standards of the day was a bestseller. ${ }^{50}$ The eponymous story, however, has attracted very little critical attention. To argue that Sargeson's place in New Zealand literary history might partly be due to covert intertextual borrowings from Mansfield, despite the disjunctive relationship usually constructed of their fictions, is to suggest continuity across the decades of New Zealand's emerging cultural nationalism. Even as his influence defined the era of the 1930s to the 1950s (the 'age of Sargeson') - he may also, at least in 'A Man and His Wife' - have found ways of transcending it by appropriating and even mocking elements of Mansfield's techniques of impersonation. These confer density and depth on his representations of moments of intensity, enabling the culturally-approved discourse of masculine reticence to be 
informed by the occluded 'feminised' subtext of vulnerability, volubility and desire. Finally, the layered narrative and disparate viewpoints in 'A Man and his Wife', when read alongside 'The Canary', confirm the complexity of the 1930s cultural nationalism that Sargeson did so much to shape: for his singular focus directed at its monocultural and largely homophobic society in fact consisted of more multiple literary and cultural formations and borrowings than he was prepared to concede in his lifetime, as indicated by his comment in the interview published in 1970: 'I was never conscious of writing in the shadow of Katherine Mansfield or reacting from her'. 51

Notes

${ }^{1}$ C. K. Stead, 'Meetings with "the Great Ghost"', in Gerri Kimber and Janet Wilson (eds), Celebrating Katherine Mansfield: A Centenary Volume of Essays (London: Palgrave MacMillan, 2011), pp. 214-28, 214, 226. W. H. New, Dreams of Speech and Violence: The Art of the Short Story in Canada and New Zealand (Buffalo and London; University of Toronto Press, 1987), pp. 139-40, comments that irrational criteria continued the case against Mansfield into the 1950s.

${ }^{2}$ Lydia Wevers, 'The Short Story', in Terry Sturm, ed., The Oxford History of New Zealand Literature (Oxford: Oxford University Press, 1991), pp. 203-68, 222.

${ }^{3}$ Lawrence Jones, Barbed Wire and Mirrors: Essays on New Zealand Prose (Dunedin: Otago University Press, 1987), p. 6; New, Dreams of Speech and Violence; Joel Gwynne, The Secular Visionaries: Aestheticism and New Zealand Short Fiction in the Twentieth Century (New York and Amsterdam: Rodopi, 2010); Mark Williams, 'Frank Sargeson: Apostle of Love', Landfall 192 (1996), pp. 209-221.

${ }^{4}$ First published in Tomorrow, 20 December 1939; see Frank Sargeson's Stories (Auckland: Cape Catley, 2010), p. 368.

${ }^{5}$ Gerri Kimber and Janet Wilson, 'Reconfiguring the National Canon: The Edinburgh Edition of the Collected Works of Katherine Mansfield', in New Zealand's Cultures: Histories, Sources, Futures, special issue of Journal of New Zealand Literature, 31:2 (2013), Rod Edmond and Janet Wilson (eds), pp.122-44.

${ }^{6}$ Sarah Ailwood, 'Anxious Beginnings: Mental Illness, Reproduction and Nation Building in 'Prelude' and Prelude to Christopher', Katherine Mansfield Studies 2 (2010), pp. 20-38.

${ }^{7}$ Frank Sargeson, 'Conversation with Frank Sargeson: An Interview with Michael Beveridge' in Frank Sargeson, Conversation in a Train and Other Critical Writing, ed. Kevin Cunningham (Auckland: Auckland University Press,1983), pp. 147-185, 153.

${ }^{8}$ Frank Sargeson, 'Katherine Mansfield', in Conversation in a Train, p. 29. He stresses that this tradition is not inevitably associated with women writers. The radio programme was broadcast in the 1YA session, 'All About Books' and published in a shorter version in The New Zealand Listener, $6^{\text {th }}$ August, 1948 as 'The Feminine Tradition: A Talk about Katherine Mansfield'.

${ }^{9}$ Stead, 'Meetings with "the Great Ghost"', in Kimber and Wilson (eds), Celebrating Katherine Mansfield, p. 214, notes the 'undertone of irritation with Mansfield'; see also Kai Jensen, Whole Men: The Masculine Tradition in New Zealand Literature (Auckland: Auckland University Press, 1996), pp. 78-79. On Sargeson's negativity towards Hyde, Sarah Shieff (ed.), Letters of Frank Sargeson (Auckland: Vintage, 2012), pp. 12, 14-15. 
${ }^{10}$ Sargeson, 'Conversation with Frank Sargeson', p. 153.

${ }^{11}$ Ibid., pp. 149, 172-74.

${ }^{12}$ New, Dreams of Speech and Violence, p. 145; Gwynne, Secular Visionaries, p. 7.

${ }^{13}$ Williams, 'Frank Sargeson: Apostle of Love', p. 232; Gwynne, Secular Visionaries, p. 59; Jensen, Whole Men, p. 172, on 'the secret alliance between feminism and masculinism' in New Zealand literature; Trevor James, 'Towards an Appropriate Language: Frank Sargeson and New Zealand (1903-1982)', London Magazine (October 1982), pp. 46-54 (46-7) on Sargeson's symbolism.

${ }^{14}$ Secular Visionaries, pp. 55-58; Williams, 'Frank Sargeson: Apostle of Love', pp. 215-16.

${ }^{15}$ Frank Sargeson, I for One... Landfall 5:2 (June 1952), pp. 89-140, 140.

${ }^{16}$ Simon During, 'Towards a Revision of Local Critical Habits', And (October 1983), pp. 85-88.

${ }^{17}$ John Newton, 'Homophobia and the Social Pattern: Sargeson's Queer Nation', Landfall 199 (2000), pp. 91-107; see Michael King, Frank Sargeson: A Life (Auckland: Viking, 1995), pp. 93-96; Chris Brickell, Mates and Lovers: A History of Gay New Zealand (Auckland: Godwit, 2008), pp. 118-20.

${ }^{18}$ Bruce King, New English Literatures: Cultural Nationalism in a Changing World (London: Palgrave MacMillan, 1980), p. 141.

${ }^{19}$ See Jenny's McDonnell's reading of 'The Drover's Wife' and 'The Woman at the Store', in Katherine Mansfield and the Modernist Marketplace: At the Mercy of the Public (London: Palgrave Macmillan, 2010), pp. 48-49.

${ }^{20}$ The manifesto was 'Before art can be human again, it must learn to be brutal'. J. M. Murry et al (eds), Rhythm, 1:1 (1911), p. 36.

${ }^{21}$ See Stuart Murray, Never a Soul at Home: New Zealand Literary Nationalism and the 1930s (Wellington: Victoria University Press, 1998), pp. 157-63; Lydia Wevers, "“The Sod Under my Feet": Katherine Mansfield', in Opening the Book: New Essays on New Zealand Writing, ed. Mark Williams and Michele Leggott (Auckland; Auckland University Press, 1995), pp. 31-48, 42, identifies the 'nation as metaphor' in Mansfield.

${ }^{22}$ Homi Bhabha, 'DissemiNation', in Homi K. Bhabha (ed.), Nation and Narration (London and New York: Routledge, 1990), pp. 291-322, 293.

${ }^{23}$ Ibid., p. 294.

24 'Katherine Mansfield: The Art of Fiction', in C. K. Stead (ed.), In the Glass Case: Essays on New Zealand Literature (Auckland: Auckland University Press, 1981), pp. 29-46, 32; Jones, Barbed Wire \& Mirrors, p. 6; Lydia Wevers, 'How Kathleen Beauchamp was Kidnapped', Women's Studies Journal 2.4 (December 1988), pp. 517.

${ }^{25}$ Katherine Mansfield, 'The Canary', in Gerri Kimber and Vincent O'Sullivan (eds), The Collected Fiction of Katherine Mansfield, vol. 2 (Edinburgh: Edinburgh University Press, 2012), pp. 511-14, 513.

${ }^{26}$ W. H. New, 'Frank Sargeson as Social Story-Teller', Landfall, 36:3 (September, 1982), pp. 343-46, 345.

${ }^{27}$ New, Among Worlds, pp. 149-50.

${ }^{28}$ Frank Sargeson, 'A Man and his Wife', in Sargeson's Stories, pp. 115-118, 115.

${ }^{29}$ Mansfield, 'The Canary', in Collected Fiction, vol. 2, p. 513.

${ }^{30}$ W. H. New, 'Sargeson as Social Story-teller', pp. 343-46, on the 'act of communication'. 
${ }^{31}$ Gayatri Gopinath, Impossible Desires: Queer Diasporas and South Asian Public Cultures (Durham: Duke University Press, 2005), p. 105.

${ }^{32}$ Sargeson, 'A Man and his Wife', p. 118; Wilson, 'Introduction', Sargeson's Stories, pp. 9-19,13.

${ }^{33}$ Letter to Elizabeth von Armin, 31 December 1922, in Vincent O'Sullivan and Margaret Scott (eds), The Collected Letters of Katherine Mansfield, vol. 5 (Oxford: Oxford University Press, 2008), p. 346.

${ }^{34}$ Mansfield, 'The Canary', in Collected Fiction, vol. 2, p. 511.

${ }^{35}$ In 'That Summer', in Sargeson's Stories, p. 162, this phrase is used of male relationships.

${ }^{36}$ Sargeson, 'A Man and his Wife', in Sargeson's Stories, p. 118.

${ }^{37}$ New, Dreams of Speech and Violence, p. 137.

${ }^{38}$ Sargeson, 'A Man and his Wife', in Sargeson's Stories, p. 117.

${ }^{39}$ Mansfield, 'The Canary', in Collected Fiction, vol. 2, p. 512.

${ }^{40}$ Sargeson, 'A Man and his Wife', in Sargeson's Stories, p. 118.

${ }^{41}$ Pamela Dunbar, Radical Mansfield: Double Discourse in Katherine Mansfield's Short Stories (London: Macmillan Press Ltd, 1997), p. 72; Anne Mounic, "“Ah, What is it? -- that I Heard": The Sense of Wonder in Katherine Mansfield's Stories and Poems', in Kimber and Wilson (eds), Celebrating Katherine Mansfield, pp. 144-57, 155-56.

${ }^{42}$ Mansfield, 'The Canary', in Collected Fiction, vol. 2, p. 512.

${ }^{43}$ Ibid., p. 514.

${ }^{44}$ Sargeson, 'A Man and his Wife', in Sargeson's Stories, p. 115.

${ }^{45}$ Ibid., p. 116.

${ }^{46}$ Mansfield, 'The Canary', in Collected Fiction, vol. 2, p. 512; see Notebooks, vol. 2, p. 291.

${ }^{47}$ Ibid., p. 513.

${ }^{48}$ Sargeson, 'A Man and his Wife', in Sargeson's Stories, p. 112.

${ }^{49}$ Mansfield, 'The Canary', in Collected Fiction, vol. 2, p. 513; Sargeson, 'A Man and his Wife', in Sargeson's Stories, p. 118.

${ }^{50}$ King, Frank Sargeson, pp. 200-01.

${ }^{51}$ Beveridge, 'Conversation with Frank Sargeson', p. 153. 